\title{
Can land value uplift deliver affordable housing? Experiences from England
}

Article

Accepted Version

Wyatt, P. (2018) Can land value uplift deliver affordable housing? Experiences from England. Journal of European Real Estate Research, 11 (1). pp. 87-101. ISSN 1753-9269 doi: https://doi.org/10.1108/JERER-02-2017-0009 Available at https://centaur.reading.ac.uk/71003/

It is advisable to refer to the publisher's version if you intend to cite from the work. See Guidance on citing.

To link to this article DOI: http://dx.doi.org/10.1108/JERER-02-2017-0009

Publisher: Emerald

All outputs in CentAUR are protected by Intellectual Property Rights law, including copyright law. Copyright and IPR is retained by the creators or other copyright holders. Terms and conditions for use of this material are defined in the End User Agreement.

\section{www.reading.ac.uk/centaur}

\section{CentAUR}

Central Archive at the University of Reading

Reading's research outputs online 
TITLE: $\quad$ Can land value uplift deliver affordable housing? Experiences from England

AUTHOR: $\quad$ Peter Wyatt

CONTACT DETAILS:

Department of Real Estate \& Planning

Henley Business School

University of Reading

Whiteknights

Reading

UK

p.wyatt@reading.ac.uk 


\section{Can land value uplift deliver affordable housing? Experiences from England}

\section{Structured Abstract}

\section{$\underline{\text { Purpose }}$}

The theoretical case for land value capture is well known but the effectiveness of affordable housing delivery as a capture mechanism is not so well documented. Building on the earlier theoretical and empirical work of Whitehead (1991 and 2007) and Crook and Whitehead (2002), this paper considers the provision of affordable housing from a land value capture viewpoint, focusing on the process by which the amount of affordable housing is determined between landowners/developers on the one hand and local planning authorities on the other.

\section{Design/Methodology/Approach}

The paper adopts a mixed mode approach to data collection. Two surveys of local planning authorities were undertaken, together with a series of case study interviews.

\section{Findings}

The paper evaluates whether land value capture has been an effective mechanism for delivering affordable housing by focusing on three principal areas: first, the political agenda in relation to land value capture and the supply of affordable housing; second, the nature and motivation of the stakeholders involved in affordable housing decision-making; and third, the use of economic models as decision tools for determining the amount and type of affordable housing are negotiated.

\section{$\underline{\text { Originality/Value }}$}

The research provides some insight into the effectiveness of local authority affordable housing targets as a means of capturing the uplift in land value that results from the grant of planning permission. 


\section{Introduction}

Planning permission is required for development in England and the grant of permission usually results in an increase in land value. England has a rather chequered history of legislation that attempted to capture, in the form of a tax, some (and at one time all) of this land value uplift; but by the early 1980s all were repealed. Instead of direct taxation, negotiated planning agreements between local planning authorities and developers/landowners have evolved as the sole mechanism by which local government has attempted to capture an element of land value. Under these planning agreements developers have been obliged to contribute, either financially or in kind, towards infrastructure provision, community investment and development mitigation. Throughout the 1990s affordable housing became an increasingly important part of these contributions, to the extent that local authorities had developed sophisticated targets for the amount of affordable housing they sought from developers and central Government were offering grant assistance to the housing associations that were acquiring the completed dwellings.

Then, in 2010, in an attempt to simplify and speed up the planning process, the Community Infrastructure Levy (CIL) was introduced and, after a very slow start, has now been adopted by approximately one third of local authorities. Originally intended as a replacement for negotiated planning agreements, CIL now sits alongside that mechanism so that developers pay CIL to help fund infrastructure provision, and negotiate the agreements to mitigate the impact of their development and to continue to provide an element of affordable housing in their residential schemes.

The CIL charging rates and the amount of affordable housing that can be sought from developers is regulated by the use of financial viability assessments, which limit the amount of land value uplift that flows from the grant of planning permission to a 'viable' proportion. In practice this approach has proved difficult to administer for reasons that centre on the use of these viability assessments, including:

- An absence of evidence on which to base valuations of a development site before and after the grant of planning permission;

- Difficulties in agreeing how much of the land value uplift should be allocated to developer contributions under CIL and negotiated planning agreements; and

- A lack consensus on how to produce viability assessments that can cope with the dynamics of real estate development.

As a consequence, a great deal of controversy now surrounds the viability testing of these land value capture mechanisms. Some of the issues raised are reminiscent of earlier attempts to levy land tax; paucity of transaction evidence and consequent lack of agreement on values, and disagreement over the proportion of land value uplift that should be captured, are two examples. But some of the problems are new: confidentiality of developer appraisals that are used to calculate the amount of land value capture; difficulty in deciding appropriate or 'competitive' returns to developers and landowners. On top of these procedural and political issues, there are growing concerns about the adequacy of the conventional method of valuing development land. Some of these concerns have been explored in the literature. Christophers (2013) examined the use of financial viability models for determining affordable housing from the perspective of performativity - the actualisation of the world of affordable housing development by the model itself. Crosby et al (2013) and Coleman et al (2013) focus on some of the more technical aspects of viability modelling, particularly input uncertainty and output sensitivity, whereas McAllister et al (2013 and 2015) question the use of industry-derived decision rules to determine viability and hence land value capture. 
This paper, therefore, evaluates whether land value capture has been an effective mechanism for delivering affordable housing by focusing on three principal areas: first, the political agenda in relation to land value capture and the supply of affordable housing; second, the nature and motivation of the stakeholders involved in affordable housing decision-making; and third, the use of economic models as decision tools for determining the amount and type of affordable housing are negotiated.

\section{Literature review}

\section{Policy context and affordable housing delivery}

Land use regulation limits the supply, and therefore increases the price, of land for regulated uses, including housing. Landowners thus receive an unearned increase in their wealth while, at the same time, the cost of housing becomes unaffordable for marginal buyers. In England, social housing used to be provided by local authorities and voluntary, often philanthropic, housing associations with the help of government loans and grants. Social housing is let at 'social rents' that are established using an 'affordability' formula based on local income levels rather than determined by local market rental levels. The housing was offered to households that found themselves economically excluded from market housing and eligibility is determined with regard to local incomes and local house prices. Then, in the 1980s, policies introduced by the Conservative Government removed the ability of local councils to use local taxes to fund social housing and central government grant funding was redirected to new housing associations. In addition, the existing stock of social housing was reduced through the mechanism of 'right to buy' that gave tenants council-owned dwellings the legal right to purchase their dwelling at a discounted price. Faced with these policies, and a central Government ideological commitment to home ownership rather than renting, many local authorities decided to transfer their social housing stock to existing and newly formed housing associations.

From 2011, housing associations (now referred to as 'private registered providers of social housing') and local authorities could also offer 'affordable rent' housing to certain categories of occupier such as key workers at rents of up to $80 \%$ of the local market rent. The supply of these affordable rented dwellings dramatically increased at the expense of the supply of social rented dwellings (see Table 1). The table shows how the numbers of various types of new-build affordable dwellings has changed over the past 25 years. On average, new-builds make up around $90 \%$ of all additional affordable dwellings in any year, the remainder being acquisitions.

\section{Table 1 here}

\section{Affordable housing delivery through planning obligations}

Local authorities sought alternative ways of delivering housing to those who could not afford to buy or rent privately. A key tool was the use of 'planning obligations'. This land value capture mechanism first appeared as 'Section 52 agreements' following enactment of the 1971 Town and Country Planning Act. Renamed 'Section 106 agreements' following enactment of the 1990 Town and Country Planning Act, these agreements enable local planning authorities to enter into legal contracts with developers to regulate aspects of a development. In the early days this regulation took the form of site-specific mitigation measures and charges were levied according to formulae for each item but gradually these obligations began to include the provision of infrastructure, community facilities - including affordable housing - and environmental improvements.

Policies that specifically encouraged the use of planning obligations to provide affordable housing began with the first 'rural exceptions policy' in 1979. This enabled local authorities to grant planning permission for dwellings on sites that would otherwise not be permitted, 
provided that only affordable homes are provided (Crook et al, 2002). A Government planning circular, Circular 1991/7 (DoE, 1991), and Planning Policy Guidance Note Number 3, PPG3 (DoE, 1992 and DETR, 2000), provided more guidance on the use of planning obligations for affordable housing. Then Circular 6/98, stated that provision of affordable housing should be a material consideration when residential planning permission is agreed, leaving it up to local government to decide what affordable meant: "The policy should define what the authority regards as affordable, but this should include both low-cost market and subsidised housing, as both will have some role to play in providing for local needs" (DETR 1998, Paragraph 9a). All of this planning guidance was abolished by Conservative-led coalition Government in 2010 and current policy is now enshrined in the National Planning Policy Framework (NPPF) (DCLG, 2012) but the premise for the supply of affordable housing via S106 planning obligations remains.

The legally binding S106 agreements to provide affordable housing as a planning obligation may take the form of a cash payment or be provided 'in kind'. The former is referred to as a 'commuted sum' and the latter is usually provided via a land contribution or provision of completed dwellings to a 'registered provider' of affordable housing at a discounted price. In kind provision is almost always preferable as it helps meet widely adopted policies that promote mixed community schemes. These S106 agreements "are in effect locally determined and negotiated betterment levies on development values, hypothecated for local needs" (Crook and Monk, 2011, p997).

As well as social and affordable rent dwellings, intermediate housing is offered to at a cost that is below market levels, in both the rental and capital markets. Intermediate rent housing is offered to occupiers who do not qualify for social rented housing and nor can they afford affordable rents. For intermediate ownership housing, shared ownership and equity loans are offered to those unable to buy a dwelling outright. Housing associations (or private registered providers) have become the main providers of new affordable homes and they have become very dependent on planning obligations for land and funding (Crook and Monk, 2011).

So planning obligations, contained within Section 106 agreements, are the current mechanisms employed by local authorities to capture part of the uplift in land value that is realised upon grant of planning consent. The provision of social housing for rent by local government has been replaced by a mechanism by which developers are required to provide affordable housing when private (market) dwellings are constructed. It is, essentially, a cross subsidy (Crook and Whitehead, 2002). The idea is that developers may reduce their land acquisition prices (thus making landowners pay) or absorb the cost as an additional development cost. The latter may affect the supply of housing but the effect may be countered by building more cheaply or more densely.

At the same time, the type or tenure of affordable housing has changed from social housing to affordable rent to intermediate ownership or shared equity and, more recently, discount market housing (for example, starter homes offered at a $20 \%$ discount to first time buyers). This shift is tied in with a change in the types of households that might be entitled to it. This is because, as the cost of housing has risen substantially in many parts of England, more and more people are excluded from the market including not only unemployed and low-income households but also key workers and first-time buyers. The shift from social housing to discount market housing is also linked to a change in Government ideology away from renting and towards home ownership. 
According to Whitehead (2007) the use of S106 to provide affordable housing was adopted by over 90 per cent of local authorities. Table 2 shows the number of new-build dwellings funded by S106 contributions ${ }^{1}$.

\section{Table 2 here}

Affordable housing, provided with the assistance of the planning system via planning obligations, has been with us in England in one way or another for at least 25 years. Recently, this local level land value capture mechanism has been joined by another - the Community Infrastructure Levy (CIL). CIL came into force in 2010 and provides local authorities in England and Wales with the opportunity to raise contributions from developers to fund infrastructure that is needed as a result of new development. CIL charging rates are based on the size and type of the new development. CIL is intended to operate alongside a scaled back system of section 106 planning obligations, which will only be used for site-specific items and affordable housing. As with S106, CIL is a local levy and it is the responsibility of planning authorities in England and Wales to decide whether to introduce it.

\section{Research method}

Using two surveys of local authorities undertaken in 2013 and 2015 on behalf of the UK Government (DCLG, 2014 and 2017), this section describes the approach taken to identify some of the key lessons that can be learnt from policies to deliver affordable housing using a land value capture mechanism.

The 2013 survey involved all local planning auhorities in England except the National Park Authorities and the London Thames Urban Development Corporation. At that time there were 366 local planning authorities in England, broken down as follows:

- District and borough councils (228)

- Metropolitan borough councils (20)

- London borough councils (32)

- City councils (36)

- County councils: two-tier (27) and unitary (8)

- National parks (9)

- Development corporations and partnerships, including the Olympic Delivery Authority (6)

- The Greater London Authority

The survey focused on the 326 unitary authorities because these are the primary negotiators of planning obligations via S106 agreements and most Government statistics refer to this grouping. The questionnaire was emailed to relevant personnel in local authority planning departments. It sought responses to questions relating to six areas of investigation:

a) The number and proportion of planning permissions that include planning obligations

b) The value of planning obligations agreed

c) The value of planning obligations likely to be delivered

d) The breakdown of planning obligations by value and category

e) The value of affordable housing delivered through s106 agreements; and

f) Policies and practices regarding re-negotiation of s106 agreements, affordable housing and the use of standard s106 agreements and charging formulae

\footnotetext{
${ }^{1}$ When S106 funding is combined with other funding sources they are recorded under 'partial grant'. These other funding sources have more or less ceased so numbers of partial grant units are likely to be very small. There is no way of knowing how partial a partial grant is. 'Pure' S106 delivery is recorded in the 'nil grant' field. Table 2 focuses on nil grant units.
} 
126 completed and usable questionnaires were returned, a response rate of $40 \%$. Using the classification of local authority 'families' adopted by Crook et al (2006) the breakdown of responses is shown in Table 3 alongside the breakdown of all local authorities.

\section{Table 3 here}

A possible problem with a questionnaire approach is that LPAs that are (relatively) more effective in securing planning obligations are more likely to hold appropriate data and respond to the survey. When extrapolating from the sample to produce a national picture, it is important to ensure that the sample is representative and includes authorities that span the urban-rural, regional and political spectrums and different rates and type of development activity. Therefore, the estimates for the number and value of planning obligations are based on a process of clustered extrapolation. Survey responses were 'grossed up' to provide estimates for the whole population of local authorities. When extrapolating from the sample, it was important to ensure that the sample was appropriately weighted, representative and included local authorities that span the urban-rural, regional and political spectrums and different rates and type of development activity.

To achieve this, local authorities were classified into seven clusters according to the characteristics of their residents and reflecting the urban/rural and socio-economic profile. Sample results were extrapolated by assuming that the average of the sample returns in a socioeconomic cluster represented all local authorities in that cluster. This average could then be multiplied by the total number of local authorities in that cluster to compute an estimate for the cluster population. Table 4 shows that the breakdown of survey returns was a good representation of the population breakdown of local authority families.

\section{Table 4 here}

The 2015 survey investigated the attitudes and experiences of local authorities that were implementing and operating CIL. The survey also investigated attitudes and experiences of those local authorities that have not yet adopted a CIL or that have decided not to implement a CIL. This sample of 'non-adopters' was a mixture of those making progress towards adoption and those that have not yet started. It was constructed so that it was comparable in terms of local authority family (see 2013 survey method) and median house price to the 'adopters' sample. Six house price groups were derived from DCLG Live Table 586, which publishes median house prices based on Land Registry data at the local authority level. Table 5 shows the breakdown of the two samples.

\section{Table 5 here}

It is important to note that the breakdown of local authorities that have adopted CIL may be different from the breakdown of all local authorities. In other words certain types of local authority may be more inclined to adopt CIL than others. Comparing CIL adopters against a sample of non-adopters in the way described above addresses this issue.

The questionnaire was structured in two parts; one for the local authorities that had adopted a CIL and the other for those that had not yet adopted a CIL. Survey questions for the local authorities that have adopted a CIL covered the following areas:

- CIL administration

- Operation of CIL

- Scaled-back planning obligations

- Comparison with situation pre CIL 
- Spending of CIL receipts

Survey questions for local authorities that have yet to adopt a CIL or have elected not to do so were based around the following areas:

- Current policies for planning obligations

- Affordable housing targets and site size thresholds

- Number and type of planning obligations agreed and delivered in 2013/14

- Costs associated with negotiating and monitoring s106 planning obligations

- Influences on the number and value of planning obligations agreed

- Value of planning obligations agreed and monies received

- CIL policy and progress

The survey therefore involved a sample of 130 local planning authorities in England. 66 completed questionnaires were returned, a response rate of 51\%. Pearson's chi-square test statistic reveals no statistically significant association between CIL adoption status and median house price group or between CIL adoption status and LA family so it can be concluded that the two samples are similar in both these respects. Also, independent samples t-tests revealed no statistically significant difference between the two samples in terms of median house prices, housing starts and planning decisions. There did not appear to be a bias in responses when classified by house price group but perhaps some bias when categorised by local authority family towards 'Commuter Belt' local authorities. However, we do not think that had a significant impact on the results.

As a final step, in-depth case study interviews were held with planning officers from 14 local authorities. Case study selection was intended to provide a reasonable spread of local authority types and locations.

\section{Research findings}

\section{Affordable housing policies}

The vast majority (87\%) of local authorities in England have a policy that requires the provision of affordable housing via planning obligations - a finding that corroborates that of Whitehead op cit. However, certain types of authorities are less likely than others to have such a policy, in particular, rural towns and old industrial centres. Most authorities do not require affordable housing to be provided on small sites, $86 \%$ of local authorities specify a threshold number of dwellings below which planning obligations in respect of affordable housing are not required. The majority set this minimum threshold somewhere between five and fifteen dwellings. For developments where affordable housing was required, there is a wide variation in the proportion of the total number of dwellings planned for the site that are required to be affordable. The proportion was calculated either by number of dwellings or by dwelling floor area and ranged from $15 \%$ to $50 \%$, with the higher proportions found in the more affluent parts of the country, predominantly London and the south east of England.

Just over half (57\%) of local authorities have a uniform affordable housing policy that is used across the whole of their jurisdiction. 30\% of authorities have a target for affordable housing provision that varies according to certain criteria. The types of criteria identified are: number of dwellings in a scheme; population size of the settlement in which the development is planned; whether the site is classified as brownfield or greenfield; or designated in some other way including on the basis of 'Housing Market Areas' or parishes, between rural/urban and sustainable urban extension sites or some other distinction between main urban areas and elsewhere. The average length of time that it takes to agree a S106 is six months. 
Table 3 summarises the main findings of four investigations of the number and value of planning obligations agreed by local authorities in England (Crook et al, 2006, 2008, 2010 and DCLG, 2014). It is important to note that, even if S106 planning obligations are agreed, the development may still not go ahead, particularly if the housing market declines (Monk et al, 2006) and it can be seen that the number of completions (in table 2 above) are far lower that those that were agreed.

\section{Table 6 here}

\section{The impact of CIL on affordable housing}

One of the key differences between CIL and planning obligations is that CIL is a fixed levy and S106 planning obligations are negotiable. This has led to concerns that, where scheme viability is an issue, there will be a reduction in planning obligations sought and, notably, a reduction in affordable housing that is provided. However, the survey of local authority adopters showed that only three authorities felt that the introduction of CIL had affected the delivery of affordable housing, with one stating "CIL was delivered alongside a review of the Local Plan including the affordable housing targets. In a number of locations the proportion of affordable housing sought reduced in order to achieve the necessary infrastructure investment" and another that "...on a few marginal schemes a reduction in affordable housing provision has been accepted when accompanied by an appropriate viability assessment, however this was the same under the S106 regime." On the other hand, 33 authorities felt that CIL had not had an impact on the delivery of affordable housing, with others stating that it was too soon to tell.

The issue of the potential impact of CIL on affordable housing development was discussed with 14 case study authorities. Of these, only two commented that the introduction of CIL had had a direct impact on the delivery of affordable housing. In one case, this had affected the tenure mix of the affordable housing achieved (although the overall percentage had held up) and the other authority had been achieving a lower percentage post CIL. Half of the case studies said that there had been no change (or only a minor decrease) and the others either did not know or felt that it was too early to tell. In one case, a downturn in delivery of affordable housing was attributed to the then national site size threshold for affordable housing of 10 dwellings. As context for their assessment, it was highlighted that there are, "Difficulties with or without CIL, it is resisted regardless." Changing market conditions were also commented on by some interviewees with two mentioning that 'improving market conditions' had overcome any impact that CIL might have on viability. Another interviewee commented that affordable housing delivery had been declining prior to the introduction of CIL and its continuing decline post CIL was part of this wider trend. Attention was drawn by at least two interviewees to comments from developers before its introduction that CIL would have an adverse impact on scheme viability but that they had proceeded to bring forward their schemes with CIL in place: "...have got a current application where a developer said they couldn't afford CIL pre adoption but have now gone all the way through the process and paid the CIL..."

Although it is too early to assess the impact of CIL on development activity and viability, there may be a greater tendency to renegotiate existing s106 agreements in light of introduction of CIL and revised s106. The relationship between CIL and affordable housing policy has important implications for scheme viability and early evidence from authority studies suggests that this can be a complex relationship bringing into play the impact of different affordable housing tenure options as well. There then remains the way in which CIL operates in relation to remaining s106 requirements to deal with measures for site-specific mitigation. Possible issues include: CIL is a first charge so S106 more marginal and therefore harder to negotiate, and the cumulative impact of CIL, S106 and new building regulations. 


\section{Affordable housing negotiations}

The surveys revealed that negotiations remain a concern for some authorities: "The council has scaled back its planning obligation requirements since adoption of CIL. However, affordable housing was already the most difficult S106 item to negotiate, and this remains the case" and "Sitespecific needs have not changed; in addition the question of viability of affordable housing is now raised more frequently."

The Growth and Infrastructure Act 2013 inserted new clauses into S106 of the 1990 Town and Country Planning Act that introduces a new application and appeal procedure for the review of planning obligations on planning permissions which relate to the provision of affordable housing. The changes require a council to assess the viability arguments, to renegotiate previously agreed affordable housing levels in a S106, and change the affordable housing requirement or face an appeal. An appeal can be made if the authority does not modify the planning obligation as requested, or fails to make a determination within a specified time.

In order to assess the extent to which local authorities were being flexible on S106 agreements in response to changing market conditions, respondents to the 2013 survey were asked about the numbers of S106 agreements being renegotiated. 36\% of local authorities had renegotiated S106 planning agreements during the 2011-12 financial year, including reductions in the amount of affordable housing provision and in the amount of commuted sum payments in lieu of affordable housing. In one case the affordable housing requirement was removed altogether. There were also changes to affordable housing tenure (e.g. from social rented to affordable rent), a switch from affordable housing provision to commuted payment, a change the timing of the provision of affordable housing and a change of clause relating to status of purchasers of affordable housing. Nearly all requests to renegotiate s106 agreements in 2011/12 led to a change in the planning agreement.

Local authorities were also asked, as at 1 April 2012, how many s106 agreements were in the process of being renegotiated. A breakdown of the results by local authority family is shown in Table 4. Over two thirds of renegotiations were taking place in rural areas. There were relatively low numbers of renegotiations taking place in London.

\section{Table 7 here}

\section{Discussion}

There is an absence of clear and consistent affordable housing policy at national level. There is guidance but no standardised approach. Policies for what is essentially a betterment levy are set locally and negotiated individually. As a result there is an emergence of calculative practices. These have been discussed by Christophers (2014) and McAllister et al (2015) but they have manifested to a greater extent in the case of affordable housing than for other types of planning obligation. This is because an affordable housing contribution is widely regarded by the development industry as satisfying a social or community need rather than mitigating the impact of a development or providing infrastructure that might legitimately be regarded as directly required by the development.

The focus for these calculative practices is viability. Development viability appraisals are required to be undertaken by local authorities at various junctures in the planning process. As far as affordable housing in concerned, viability appraisals are required when setting affordable housing targets as part of the local plan process. Developers are able to contest these targets in relation to specific planning applications and, as seen from the provisions of the Growth and 
Infrastructure Act referred to above, such contests are encouraged for extant planning consents that include residential development and affordable housing provision.

It is worth noting that inconsistency in both policy and practice leads to uncertainty and, in a market for what are essentially real options, in which landowners have an option to develop their land and are able to limit downside risk by choosing to delay exercise of the option, this uncertainty increases the value of these options. The rationale is captured by Whitehead (2007); landowners may not bring forward land for development because they anticipate being able to use the land more profitably in the future (perhaps as a result of policy change).

Nearly a decade ago Whitehead stated that "...while using the land-use planning system to support the provision of affordable housing may be one valuable tool in a government's armoury, the land-use planning system alone is very unlikely to be a primary source of additional affordable housing. The English planning system is certainly among the most favourable to such an approach and S106 is increasingly successful in its own terms. However, even in England, large-scale government financial support is also necessary if affordable housing provision targets are to be achieved" (Whitehead, 2007: 41). Since that time CIL has been introduced and central government policy has shifted away from the provision of social rented housing. The impact on the supply of affordable housing has been negative.

Crook and Monk (2011) offer a more optimistic note: "This approach to taxing development value has almost certainly raised far more than each of the three previous attempts to tax betterment through nationally determined and levied taxes. This is for two reasons. First, the discretionary and negotiating character of planning gain enables LPAs [local planning authorities] to structure their policies and negotiations so that 'tax' is collected whilst sites remain viable and get developed. Second, the rapid increase in house prices and development value has been key to the success of negotiations and hence the collection of the 'tax'”' (p1008). Perhaps, though, this degree of optimism is misplaced as central government shifts policy away from affordable housing supply via the planning system and towards a more direct provision of discounted market homes from house builders.

\section{Conclusions}

To conclude, three points can be made. First, only a proportion, perhaps somewhere between $25 \%$ and $50 \%$ of land value uplift is being captured for planning obligations. Because affordable housing planning obligations are contained within S106 planning agreements there is no guarantee that the dwellings will be delivered. Even when negotiations are complete and a legally binding S106 agreement is in place, the affordable housing may not necessarily be delivered. There is no guarantee of supply and it is greatly affected by market activity. It is also worth noting that the system in operation in England is not really a betterment levy at all, it is limited to land that is being brought forward for development and therefore does not capture any land value uplift received by land that is not being (re)developed.

Second, recent Government policy has encouraged landowners with extant planning agreements to contest the amount of affordable housing that had been agreed. This is part of a wider shift in Conservative-led Government philosophy that is keen to promote home ownership rather than renting. The result is that, although the numbers of affordable housing are increasing, it hides a shift from social housing for those in very low incomes to discount market housing to first time buyers and key workers. But it is not only at central government level that this policy emphasis can be observed. Locally elected councillors set affordable housing targets and it may not be a policy priority to provide affordable housing in the locality. Also, because of the constraint imposed by viability testing there may be a trade-off between provision of affordable housing via S106 and the capture of infrastructure revenue via CIL. The balance between these two competing claims on land value uplift is a local policy decision. This 
leads to the third point is that the amount of affordable housing delivered through planning obligations is in danger of being eroded by the introduction of CIL as this is a fixed charge on land value uplift while planning obligations are negotiable.

Finally, there has been a dearth of policy guidance in relation to the delivery of affordable housing via land value capture. This may, at least in part, be due to reluctance by government to admit explicitly that that is what it is, given the failure of previous attempts to tax land value uplifts upon grant of planning permission. The use of planning obligations to deliver affordable housing has evolved from the local level, latterly encouraged by the Labour Government of the mid-1990s to 2010 and then tolerated by the Conservative-led coalition Government. However, this tolerance has its limits and the gradual shift to discount market housing for owneroccupation has substantially changed the nature of affordable housing since its introduction in the early 1990s. Notwithstanding the change in tenure, there is no doubt that, with negotiated quotas of affordable housing being driven by arguments over viability, local authorities are in a weak position in terms of access to information, expertise and resources compared to their landowner and developer counterparts. This is an area in urgent need of reform.

An important first step is to improve data on land prices. Without a proper understanding of the nature of the land value uplift it is difficult for local authorities to negotiate delivery of affordable housing that captures a satisfactory proportion of that uplift. How much should be captured? How does the capture of land value uplift for affordable housing trade off against capture for infrastructure provision? At the moment local authorities are working in an information vacuum. This is why local authorities favour existing use value as a basis for determining landowner return - they have no access to market information on what returns or prices landowners are achieving.

This is a situation that is exacerbated by the heterogeneity of sites and site values. There are substantial differences in land value uplift between high value urban areas (particularly London) and lower value rural areas. Essentially, land value in urban areas is a much higher proportion of the total costs of any new development scheme. This means that land value capture should be higher but it also means that disputes and appeals are more commonplace because the stakes are higher. In rural areas, where land value is a smaller proportion of overall costs, small changes to the other development inputs such as sale prices and build costs can easily turn a viable scheme into an unviable one. This effect is often hidden because rural land sales tend to involve larger sites and therefore large sums of money to the landowner.

Finally, improved access to and availability of land transaction data should mean that it becomes a more transparent exercise for local authorities to set out their spending priorities for land value capture in terms of infrastructure provision, social rented housing, affordable rented housing and discount market housing. This transparency is key to reducing the level of public disquiet and that surrounds the often-opaque negotiations over the capture of land value uplift for these purposes.

\section{References}

Christophers, B. (2014) Wild dragons in the city: urban political economy, affordable housing development and the performative worldmaking of economic models, International Journal of Urban and Regional Research, 38:1, 79-97

Coleman C, Crosby N, McAllister P, and Wyatt, P. (2013) Development appraisal in practice: Some evidence from the planning system, Journal of Property Research 30: 2, 144-165

Crook, A. and Monk, S. (2011) Planning gains, providing homes, Housing Studies, 26(7-8), 9971018

Crook, T. and Whitehead, C. (2002) Social housing and planning gain: is this an appropriate way of providing affordable housing? Environment and Planning A, 34, 1259-1279 
Crook, T., Currie, J., Jackson, A., Monk, S., Rowley, S., Smith, S. And Whitehead, C. (2002) Planning gain and affordable housing: making it count, Joseph Rowntree Foundation, York, UK

Crook, A., Henneberry, J., Rowley, S. and Watkins, C. with the Halcrow Group (2006), Valuing Planning Obligations in England, London, Communities \& Local Government.

http://webarchive.nationalarchives.gov.uk/20120919132719/http://www.communities.go v.uk/archived/publications/planningandbuilding/valuing-planning

Crook, A., Henneberry, J., Rowley, S., Smith, R., \& Watkins, C. (2008), Valuing Planning Obligations in England; Update Study for 2005-06, London, Communities \& Local Government. http://webarchive.nationalarchives.gov.uk/20120919132719/http://www.communities.go v.uk/documents/planningandbuilding/pdf/obligationsupdatestudy.pdf

Crook, A., Dunning, R., Ferrari, E., Henneberry, J., Rowley, S., Watkins, C., Burgess, G., Lyall-Grant, F., Monk, S., \& Whitehead, C. (2010), The Incidence, Value and Delivery of Planning Obligations in England in 2007-08, London, Communities \& Local Government. http://www.cchpr.landecon.cam.ac.uk/Downloads/VPO3\%20final\%20report.pdf

Crosby, N., McAllister, P. and Wyatt, P. (2013) Fit for planning? An evaluation of the application of development viability appraisal models in the UK planning system, Environment and Planning $B, 40,3-22$

DCLG (2002) Delivering affordable housing through planning policy, Department for Communities and Local Government, HMSO, London

DCLG (2014) Section 106 Planning Obligations in England, 2011-12: Report of study, Department for Communities and Local Government, London

DCLG (2015) Land value estimates for policy appraisal, Department for Communities and Local Government, London

DCLG (2017) The value, impact and delivery of the Community Infrastructure Levy, Department for Communities and Local Government, London

DETR (1998) Circular 6/98: Planning \& Affordable Housing, Department for the Environment, Transport and the Regions, HMSO, London

DETR (2000) Planning Policy Guidance Note 3: Housing, Department for the Environment, Transport and the Regions, HMSO, London

DoE (1991) Planning and Affordable Housing. Circular 1991/7, Department of the Environment, HMSO, London

DoE (1992) Planning Policy Guidance Note 3 (Revised): Housing, Department of the Environment, HMSO, London

McAllister, P., Wyatt, P. and Coleman, C. (2013) Fit for policy? Some evidence on the application of development viability models in the United Kingdom planning system, Town Planning Review, doi: 10.3828/tpr.2013.26

McAllister, P., Street, E. and Wyatt, P. (2015) Governing calculative practices: an investigation of development viability modelling in the English planning system, Urban Studies, doi: $10.1177 / 0042098015589722$

Whitehead, C. (1991) From need to affordability: an analysis of UK housing objectives, Urban Studies, 28:6, 871-887

Whitehead, C. (2007) Planning policies and affordable housing: England as a successful case study? Housing Studies, 22:1, 25-44 
Table 1: New-build affordable dwelling completions by type of scheme, England

\begin{tabular}{|c|c|c|c|c|c|c|}
\hline & Social Rent & $\begin{array}{c}\text { Affordable } \\
\text { Rent }\end{array}$ & $\begin{array}{l}\text { Intermediate } \\
\text { Rent }\end{array}$ & $\begin{array}{c}\text { Shared } \\
\text { Ownership }\end{array}$ & $\begin{array}{c}\text { Affordable } \\
\text { Home } \\
\text { Ownership }\end{array}$ & Total \\
\hline 1991-92 & 21,770 & .. & .. & .. & 1,190 & 22,960 \\
\hline 1992-93 & 39,510 & .. & .. & .. & 1,490 & 41,000 \\
\hline 1993-94 & 40,270 & .. & .. & .. & 2,460 & 42,730 \\
\hline 1994-95 & 40,720 & .. & .. & .. & 5,450 & 46,170 \\
\hline $1995-96$ & 44,220 & .. & .. & .. & 5,750 & 49,970 \\
\hline $1996-97$ & 29,600 & .. & .. & .. & 4,010 & 33,610 \\
\hline $1997-98$ & 24,020 & .. & .. & .. & 4,200 & 28,210 \\
\hline 1998-99 & 22,620 & .. & .. & .. & 3,930 & 26,550 \\
\hline 1999-00 & 19,610 & .. & .. & .. & 2,750 & 22,360 \\
\hline 2000-01 & 18,230 & .. & .. & .. & 2,710 & 20,940 \\
\hline 2001-02 & 18,640 & .. &.. & .. & 3,100 & 21,740 \\
\hline 2002-03 & 17,510 & .. &.. & .. & 3,590 & 21,100 \\
\hline 2003-04 & 18,370 & .. & 260 & .. & 5,260 & 23,890 \\
\hline 2004-05 & 18,790 & .. & 680 & .. & 7,460 & 26,930 \\
\hline 2005-06 & 20,510 & .. & 1,370 & .. & 11,380 & 33,260 \\
\hline 2006-07 & 21,440 & .. & 1,110 & .. & 13,680 & 36,220 \\
\hline 2007-08 & 25,660 & .. & 1,050 & .. & 17,460 & 44,180 \\
\hline 2008-09 & 27,600 & .. & 1,690 & .. & 14,940 & 44,220 \\
\hline 2009-10 & 30,400 & .. & 1,910 & .. & 15,750 & 48,060 \\
\hline 2010-11 & 35,180 & .. & 2,390 & .. & 15,570 & 53,140 \\
\hline 2011-12 & 34,920 & 770 & 1,700 & .. & 15,460 & 52,840 \\
\hline $2012-13$ & 16,870 & 6,050 & 820 & .. & 15,760 & 39,510 \\
\hline 2013-14 & 10,220 & 15,840 & 690 & .. & 9,890 & 36,640 \\
\hline 2014-15 & 8,450 & 35,420 & 250 & .. & 14,460 & 58,500 \\
\hline 2015-16 & 5,820 & 14,390 & 1,320 & 4,020 & 3,100 & 28,650 \\
\hline
\end{tabular}

Source: DCLG Live Table 1009 
Table 2: New build affordable dwellings funded by $S 106$ contributions by type of scheme, England

\begin{tabular}{|l|r|r|r|r|r|}
\hline & $\begin{array}{c}\text { Social } \\
\text { Rent }\end{array}$ & $\begin{array}{c}\text { Affordable } \\
\text { Rent }\end{array}$ & $\begin{array}{c}\text { Affordable and } \\
\text { Low Cost Home } \\
\text { Ownership }\end{array}$ & $\begin{array}{c}\text { Shared } \\
\text { Ownership }\end{array}$ & Total \\
\hline $2000-01$ & 750 &.. & 450 &.. & 1,200 \\
\hline $2001-02$ & 1,070 &.. & 1,060 &.. & 2,130 \\
\hline $2002-03$ & 720 &.. & 1,250 &.. & 1,970 \\
\hline $2003-04$ & 1,580 &.. & 1,550 &.. & 3,130 \\
\hline $2004-05$ & 1,530 &.. & 1,900 &.. & 3,430 \\
\hline $2005-06$ & 2,550 &.. & 3,810 &.. & 6,360 \\
\hline $2006-07$ & 2,750 &.. & 4,440 &.. & 7,190 \\
\hline $2007-08$ & 3,450 &.. & 4,910 &.. & 8,360 \\
\hline $2008-09$ & 3,430 &.. & 3,440 &.. & 6,870 \\
\hline $2009-10$ & 2,140 &.. & 1,590 &.. & 3,730 \\
\hline $2010-11$ & 2,169 &.. & 1,714 &.. & 3,883 \\
\hline $2011-12$ & 2,325 & 41 & 1,722 &.. & 4,088 \\
\hline $2012-13$ & 2,217 & 391 & 1,834 &.. & 4,442 \\
\hline $2013-14$ & 3,333 & 3,698 & 4,541 &.. & 11,572 \\
\hline $2014-15$ & 3,024 & 5,178 & 6,172 &.. & 14,374 \\
\hline $2015-16$ & 3,021 & 3,529 & 2,829 & 1,828 & 11,207 \\
\hline
\end{tabular}

Source: The old version of DCLG Live Table 1000 (from 2015 this table no longer breaks down affordable dwellings by funding source) and DCLG Live Table 1011.

Table 3: 2013 survey responses

\begin{tabular}{|l|c|c|}
\hline \multicolumn{1}{|c|}{ Local authority family } & $\begin{array}{c}\text { Number of responses } \\
\text { (and \% of total } \\
\text { responses) }\end{array}$ & $\begin{array}{c}\text { Number of all local } \\
\text { authorities (and \% of } \\
\text { total) }\end{array}$ \\
\hline Rural England & $39(31 \%)$ & $103(32 \%)$ \\
\hline Rural Towns & $22(17 \%)$ & $57(17 \%)$ \\
\hline Urban England & $17(13 \%)$ & $71(22 \%)$ \\
\hline Prosperous Britain & $26(21 \%)$ & $40(12 \%)$ \\
\hline Existing Urban Centres & $14(11 \%)$ & $29(9 \%)$ \\
\hline London & $8(6 \%)$ & $26(8 \%)$ \\
\hline ENGLAND & $126(100 \%)$ & $326(100 \%)$ \\
\hline
\end{tabular}

Table 4: Local authority 'families'

\begin{tabular}{|l|c|c|c|c|}
\hline \multicolumn{1}{|c|}{ Family } & Population & $\mathbf{\%}$ & Sample & $\mathbf{\%}$ \\
\hline Rural England (RE) & 103 & $32 \%$ & 39 & $31 \%$ \\
\hline Rural Towns (RT) & 57 & $17 \%$ & 22 & $17 \%$ \\
\hline Urban England (UE) & 71 & $22 \%$ & 17 & $13 \%$ \\
\hline Prosperous Britain (PB) & 40 & $12 \%$ & 26 & $21 \%$ \\
\hline Existing Urban Centres (EUC) & 29 & $9 \%$ & 14 & $11 \%$ \\
\hline London & 26 & $8 \%$ & 8 & $6 \%$ \\
\hline TOTAL & 326 & $100 \%$ & 126 & $100 \%$ \\
\hline
\end{tabular}


Table 5: CIL adopters and matched sample of non-adopters

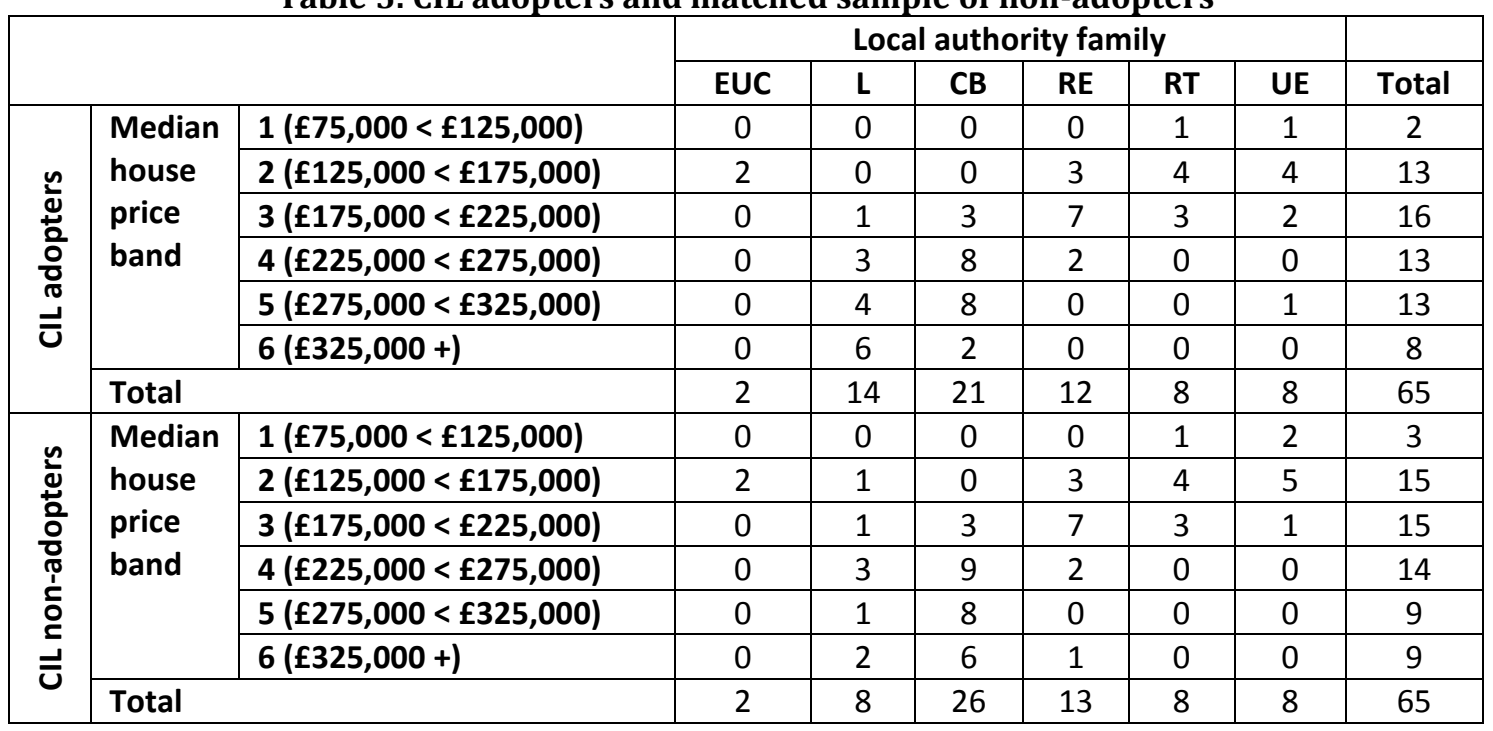

Table 6: Planning obligations agreed

\begin{tabular}{|c|c|c|c|c|}
\hline $\begin{array}{l}\text { Year of survey: } \\
\text { Financial year to which each survey relates: }\end{array}$ & $\begin{array}{c}2006 \\
(2003 / 04)\end{array}$ & $\begin{array}{c}2008 \\
(2005 / 06)\end{array}$ & $\begin{array}{c}2010 \\
(2007 / 08)\end{array}$ & $\begin{array}{c}2014 \\
(2011 / 12)\end{array}$ \\
\hline $\begin{array}{l}\text { Average number of planning agreements per } \\
\text { local authority }\end{array}$ & 25 & 25 & 30 & 20 \\
\hline Number of affordable homes & 31,500 & 44,400 & 48,000 & 32,000 \\
\hline $\begin{array}{l}\text { Estimated value of affordable housing } \\
\text { obligations }\end{array}$ & $f 1.2 \mathrm{bn}$ & $f 2 b n$ & $f 2.6 \mathrm{bn}$ & $f 2.3 b n$ \\
\hline $\begin{array}{l}\text { Estimated value of planning obligations, } \\
\text { excluding affordable housing }\end{array}$ & $f 0.7 \mathrm{bn}$ & $f 2 b n$ & $f 2.2 \mathrm{bn}$ & f1.4bn \\
\hline Estimated total value of planning obligations & f1.9bn & f4.0bn & f4.8bn & f3.7bn \\
\hline
\end{tabular}

Note: values are nominal figures

(Source: Crook et al, 2006, 2008, 2010 and DCLG, 2014)

Table 7: Number of s106 planning agreements that were in the process of being renegotiated on 1 April 2012

\begin{tabular}{|l|c|}
\hline Local authority group & Total \\
\hline Rural England & 70 \\
\hline Rural Towns & 38 \\
\hline Urban England & 10 \\
\hline Commuter Belt & 20 \\
\hline Existing Urban Centres & 18 \\
\hline London & 8 \\
\hline ENGLAND & 164 \\
\hline
\end{tabular}

